\title{
Physical Characteristics at Different Ages
}

\author{
Características Físicas en Diferentes Edades
}

*Agron M. Rexhepi; **B Behlul Brestovci \& ${ }^{* * *}$ Asllan Krasniqi

\begin{abstract}
REXHEPI, A. M.; BRESTOVCI, B. \& KRASNIQI, A. Physical characteristics at different ages. Int. J. Morphol., 29(1):105-111, 2011.

SUMMARY: The purpose of this study was to study, observe, and clarify the dynamics of physical growth, as well as changes of some morphometrical and physiological variables of Kosovo population. 17,894 males from Kosovo between 6 and 51 years of age and older, were measured:. body height, body weight, BMI, systolic pressure, diastolic pressure, heart rate, and VO max were recorded. The measurement data were processed through these descriptive statistical parameters: Mean, Standard-Deviation and the Coefficient of Variation, SD shows the similar dispersion of results between one age and another. CV signifies the reliability of the measurements that were carried out. The curve of body height for individuals between 6 and 17 years of age shows increases, for individuals between 18 and 40 years of age shows stable values, while for indiividuals above 40 years of age indicate a decrease. Body height difference between adults shows that adults between 18 and 30 years old have the higher body height values, compared with the other two groups of tested adults. Body weight for individuals between 6 and 50 years old shows consistent increase of value. In individuals above 51 years of age, body weight decreases rapidly. According to BMI values individuals between 6 and 13 years of age were underweight. Those between 14 and 35 years of age, as well as those above 51 years of age showed normal weight. On the other hand, those between 36 and 50 years of age were slightly overweight. Systolic and diastolic blood pressure values were higher as age increased, however were not above normal values. The best results of $\mathrm{HR}$ and $\mathrm{VO}_{2}$ max were reported in adults between 19 and 27 years of age.
\end{abstract}

KEY WORDS: Body height; Body weight; BMI; Systolic pressure; Diastolic pressure; Heart rate; VO max.

\section{INTRODUCTION}

Growth and development are the main characteristics of pediatric age that are part of man who from birth to maturity.

These two features are concepts closely related to one another, as in normal conditions they move forward together (Rexhepi, 2009). However, they can be distinguished as well differentiated, and in these cases the progression of development can be noticed with limited dimensional growth, or fast growth of the body with limited structural and physiological differences.

Growth and development are influenced by many different factors, which can be divided into: endogenous factors (genetic factors, endocrine glands and nervous factors) and external factors (socio-economic conditions, mental status, culture, climate and season, various diseases, physical activities, etc.). Both anthropological fields: morphological (longitudinal and transversal dimensions) and physiological field are under the influence of endogenous factors above $90 \%$ (Rexhepi \& Brestovci, 2010). Even when, impact of external factors, is much smaller in percentage than the influence of endogenous factors, if operating at the specified time and moment (when children's growth and development, as well and youth's, are in their most intensive phase) is very large (Rexhepi, 2009).

Assessment of man's development could be made by different functional tests, while assessment of man's growth could be made through morphometrical measurements. Anthropometry is the single most universally applicable, inexpensive, and non-invasive method available to assess the size, proportions, and composition of the human body (BMI). At the level of the individual, anthropometry may be

* Sport Center for Increasing of Morpho-Functional Abilities, Fitness and Nutrition, Pristina, Kosovo.

** Faculty of Special Education and Rehabilitation, University of Zagreb, Zagreb, Croatia.

**** University College for Sport Education, 10000 Pristina, Kosovo. 
used either to identify a person as being in need of special consideration, to identify an individual's somatotype, or to assess body composition of a person. Anthropometric indicators may be reflective of past events, predictive of future events, or indicative of current nutritional status (Anthropometry, 2010).

Among the morphometrical variables that indicate normal or abnormal body growth are body weight and its stature. Growth in children and body dimensions at all ages reflect the overall health and welfare of individuals and populations, anthropometry may also be used to predict performance, health, and survival (WHO, 1995). Whereas, the body weight is three-dimensional variable, stature is onedimensional variable. Dynamics of growth of these two variables is quite uneven. In their intensity these two processes, changed periodically.

Over the years, many somatic like changes occur in the elderly:

- Loss of muscle (sarcopenia) and bone mass, physical instability and frailty lead to postural alterations;

- Shrinkage of skin layers and loss of subcutaneous fat confound skinfold and other measurements;

- Contractures and loss of cognitive function prevent completion of measurements and limit ability to provide informed consent for research and treatment.

Due to bone loss, loss of cartilage, compression of joints, and gravity, both sitting height and stature decline as the individual ages. Also, elderly individuals often suffer flat feet and intervertebral disc compression that lead to additional loss of sitting height and stature (Douglas, 2008).

The aim of this study was to study, observe, and clarify the dynamics of physical growth, as well changes of some morphomterical and physiological variables of Kosovo population, from 6 years of age to above 51 years of age.

\section{MATERIAL AND METHOD}

This study is a part of a project titled "The exploration of the anthropological status of Kosovo population".

To explore morphometrical and physiological distinctions between entities at different ages, transversal search method was used. Seven variables of these two anthropological fields were measured on 17.894 males from Kosovo, from 6 years old to 51 years and older. The measurements have been done on period of time 2007 - 2010.
Measured variables:

. Body Height (Stature);

. Body Weight;

. Body Mass Index (BMI);

. Systolic Blood Pressure;

. Diastolic Blood Pressure;

. Heart Rate;

. Absolute Maximal Oxygen Uptakes (VO2max.abs).

Following the definitions of International Biological Program the morphometrical measurements were taken by the classic anthropometrical instruments (long anthropometer, classic weigher) (Rexhepi, 2008).

Body mass index was used to estimate a healthy body weight based on a person's height. It is defined as the individual's body weight divided by the square of his or her height (Centers for Disease Control and prevention, 2010; Body Mass Index, 2010).

The term blood pressure refers to the pressure measured at a person's upper arm (inside of an elbow, at the brachial artery). This variable was measured using a sphygmomanometer and stethoscope.

The heart rate was measured by stethoscope on cordapex.

Absolute maximal oxygen uptake (VO2max.abs.) was calculated by Dobeln formula.

The measurements' data were processed through these descriptive statistical parameters:

- Mean (X), Standard Deviation (St. Dev.), and the Coefficient of Variation (CV).

The coefficient of variation represents the ratio of the standard deviation to the mean, and it is a useful statistic for comparing the degree of variation from one data series to another, even if the means are drastically different from each other.

$$
\mathrm{CV}=(\mathrm{X} / \mathrm{St} . \text { Dev. }) \mathrm{x} 100
$$

\section{RESULTS}

Data of Table I show the movement of mean values of seven measured variables for each group of individuals from one age to another. All measured variables' in generally, except heart rate, with increase of age show the increase of 
their values. While the heart rate, with increasing of age, shows decrease of its values.

Data of Table II show the values of standard deviation for each measured variable, of each group of entities, according to their age. This statistical measure indicates how much variation, each variable has from the mean value, respectively, their dispersion around the mean value. A low standard deviation indicates that the data points tend to be very close to the mean, whereas high standard deviation indicates that the data is spread out over a large range of values. Except variable of body height, the other variables have relatively low values of standard deviation. The simi- lar dispersion of standard deviation from one age to another, for values of all measured variables, signifies the reliability of the measurements that were done.

The coefficient of variation for each variable, of individuals of different ages, which is contained in the data of Table III, is a very important measure of reliability. It is very useful in explaining the standard deviation of data which must always be understood in the context of the mean of the data. The values of coefficient of variation that contained in Table III are relatively low. Their similar dispersion from one age to another for all measured variables indicates the reliability of the measurements that have been done.

Table I. Mean values of measured variables.

\begin{tabular}{|c|c|c|c|c|c|c|c|c|}
\hline $\begin{array}{c}N^{\circ} \text { of } \\
\text { entities }\end{array}$ & Ages & Body Height & Weight & BMI & Sist BP & Diast BP & HR0' & $\mathrm{VO}_{2}$ max.abs \\
\hline 57 & 6 & 1211 & 21.3 & 14.4 & 92 & 57 & 102 & $\mathrm{x}$ \\
\hline 177 & 7 & 1245 & 22.9 & 14.7 & 95 & 60 & 100 & 1.8 \\
\hline 179 & 8 & 1300 & 25.6 & 15.1 & 97 & 62 & 95 & $\mathrm{x}$ \\
\hline 249 & 9 & 1351 & 27.9 & 15.2 & 102 & 67 & 97 & 2.4 \\
\hline 283 & 10 & 1407 & 33.3 & 16.6 & 104 & 70 & 91 & 2.4 \\
\hline 592 & 11 & 1457 & 37.2 & 17.4 & 105 & 72 & 87 & 2.7 \\
\hline 1078 & 12 & 1503 & 40.1 & 17.6 & 106 & 72 & 86 & 2.6 \\
\hline 1308 & 13 & 1566 & 44.7 & 18.0 & 108 & 73 & 84 & 2.7 \\
\hline 1368 & 14 & 1643 & 51.1 & 18.8 & 112 & 75 & 83 & 2.8 \\
\hline 1425 & 15 & 1705 & 57.0 & 19.6 & 115 & 77 & 80 & 3.0 \\
\hline 1457 & 16 & 1746 & 62.4 & 20.4 & 116 & 77 & 78 & 3.2 \\
\hline 1707 & 17 & 1763 & 65.8 & 21.1 & 116 & 77 & 75 & 3.3 \\
\hline 1591 & 18 & 1773 & 68.2 & 21.7 & 116 & 77 & 73 & 3.4 \\
\hline 1239 & 19 & 1776 & 69.5 & 22.0 & 117 & 77 & 72 & 3.5 \\
\hline 929 & 20 & 1780 & 70.8 & 22.3 & 116 & 77 & 71 & 3.5 \\
\hline 760 & 21 & 1784 & 72.6 & 22.8 & 118 & 78 & 71 & 3.6 \\
\hline 616 & 22 & 1784 & 73.0 & 23.0 & 117 & 78 & 71 & 3.5 \\
\hline 436 & 23 & 1780 & 73.7 & 23.3 & 119 & 79 & 72 & 3.5 \\
\hline 367 & 24 & 1780 & 74.4 & 23.5 & 116 & 78 & 71 & 3.5 \\
\hline 284 & 25 & 1787 & 75.4 & 23.6 & 120 & 80 & 70 & 3.4 \\
\hline 233 & 26 & 1786 & 75.7 & 23.7 & 117 & 79 & 70 & 3.5 \\
\hline 191 & 27 & 1780 & 75.2 & 23.7 & 119 & 79 & 71 & 3.3 \\
\hline 178 & 28 & 1782 & 76.0 & 23.8 & 119 & 81 & 71 & 3.4 \\
\hline 149 & 29 & 1773 & 75.9 & 24.1 & 117 & 79 & 73 & 3.3 \\
\hline 113 & 30 & 1764 & 75.4 & 24.2 & 117 & 80 & 70 & 3.2 \\
\hline 450 & $31-35$ & 1779 & 77.4 & 24.4 & 119 & 80 & 72 & 3.2 \\
\hline 226 & $36-40$ & 1771 & 80.8 & 25.7 & 121 & 82 & 74 & 2.9 \\
\hline 182 & $41-50$ & 1762 & 82.7 & 26.6 & 126 & 84 & 78 & 2.8 \\
\hline 70 & $51<$ & 1680 & 69.8 & 24.7 & 137 & 82 & 80 & 2.5 \\
\hline
\end{tabular}


REXHEPI, A. M.; BRESTOVCI, B. \& KRASNIQI, A. Physical characteristics at different ages. Int. J. Morphol., 29(1):105-111, 2011.

Table II. Standard deviation of measured variables.

\begin{tabular}{|c|c|c|c|c|c|c|c|}
\hline Ages & Body height & Weight & BMI & Sist BP & Diast BP & HRO' & $\mathrm{VO}_{2}$ max.abs \\
\hline 6 & 56.07 & 3.59 & 1.45 & 10.15 & 8.06 & 11.55 & $\mathrm{x}$ \\
\hline 7 & 63.19 & 4.00 & 1.60 & 10.58 & 9.64 & 14.45 & .00 \\
\hline 8 & 64.50 & 4.71 & 1.76 & 10.59 & 9.34 & 13.15 & $\mathrm{x}$ \\
\hline 9 & 73.51 & 5.86 & 2.01 & 9.45 & 8.53 & 15.09 & 0.15 \\
\hline 10 & 74.01 & 7.93 & 2.53 & 11.74 & 8.31 & 15.18 & 0.23 \\
\hline 11 & 76.80 & 8.96 & 3.14 & 10.41 & 7.90 & 12.95 & 0.37 \\
\hline 12 & 76.56 & 8.94 & 2.90 & 10.40 & 7.88 & 12.70 & 0.38 \\
\hline 13 & 88.82 & 10.00 & 2.69 & 10.77 & 8.26 & 12.48 & 0.26 \\
\hline 14 & 89.54 & 10.59 & 2.60 & 11.75 & 7.91 & 12.93 & 0.44 \\
\hline 15 & 75.71 & 9.46 & 2.36 & 11.68 & 8.04 & 13.31 & 0.47 \\
\hline 16 & 68.53 & 8.76 & 2.26 & 11.34 & 7.40 & 12.25 & 0.34 \\
\hline 17 & 62.79 & 8.03 & 2.12 & 12.15 & 7.54 & 11.96 & 0.31 \\
\hline 18 & 63.34 & 7.97 & 2.05 & 12.67 & 8.03 & 11.67 & 0.29 \\
\hline 19 & 64.43 & 8.04 & 2.01 & 12.76 & 7.82 & 11.67 & 0.33 \\
\hline 20 & 64.15 & 8.06 & 2.08 & 12.61 & 7.68 & 11.53 & 0.33 \\
\hline 21 & 64.04 & 8.28 & 2.10 & 11.76 & 6.85 & 11.99 & 0.32 \\
\hline 22 & 64.48 & 8.48 & 2.19 & 12.30 & 7.62 & 11.75 & 0.33 \\
\hline 23 & 65.19 & 8.33 & 2.08 & 13.35 & 8.23 & 12.30 & 0.37 \\
\hline 24 & 64.90 & 9.07 & 2.20 & 12.88 & 8.24 & 12.56 & 0.37 \\
\hline 25 & 63.04 & 9.49 & 2.36 & 15.26 & 7.58 & 11.29 & 0.38 \\
\hline 26 & 66.25 & 8.93 & 2.28 & 12.20 & 8.19 & 12.46 & 0.44 \\
\hline 27 & 57.20 & 8.22 & 2.27 & 12.77 & 7.68 & 14.10 & 0.34 \\
\hline 28 & 67.47 & 8.75 & 2.22 & 14.14 & 7.52 & 16.31 & 0.40 \\
\hline 29 & 59.03 & 10.37 & 2.80 & 11.71 & 8.35 & 11.90 & 0.35 \\
\hline 30 & 69.10 & 10.06 & 2.58 & 10.39 & 6.91 & 9.89 & 0.43 \\
\hline $31-35$ & 62.67 & 10.27 & 2.78 & 12.42 & 7.42 & 12.25 & 0.34 \\
\hline $36-40$ & 63.72 & 10.68 & 2.79 & 15.75 & 9.35 & 11.87 & 0.38 \\
\hline $41-50$ & 57.83 & 12.12 & 3.29 & 15.40 & 8.20 & 14.09 & 0.30 \\
\hline $51<$ & 72.90 & 12.40 & 3.84 & 22.08 & 12.67 & 12.43 & .00 \\
\hline
\end{tabular}

The data of Table IV, show differences between mature groups of tested individuals, on the variable of body height. The comparisons of the results between different generations indicate that the younger generation (18-30 years old) has realized the higher values of body height, than other groups of tested individuals.

Figure 1 graphically shows the changes of body height, according to age. According to the curvature of this figure, as well data of Table I, it is easy to differentiate three different stages of the development of a human body. The up-growth part of the curvature shows the period of children and adolescents, the horizontal part of the curvature shows the period of mature age, whereas the declining part of the curvature shows the period of older age.

\section{DISCUSSION}

According to the results of this study, with regard to its purpose, we may clarify the dynamics of physical growth, as well changes of some morphomterical and physiological variables of Kosovo population, at different ages. 
REXHEPI, A. M.; BRESTOVCI, B. \& KRASNIQI, A. Physical characteristics at different ages. Int. J. Morphol., 29(1):105-111, 2011.

Table III. Coefficient of variation for measured variables.

\begin{tabular}{cccccccc}
\hline Ages & Body height & Weight & BMI & Sist BP & Diast BP & HR0' & VO2 max.abs \\
\hline 6 & 4.63 & 16.82 & 10.06 & 10.98 & 14.03 & 11.35 & x \\
7 & 5.08 & 17.50 & 10.90 & 11.19 & 16.14 & 14.51 & .00 \\
8 & 4.96 & 18.38 & 11.68 & 10.87 & 14.99 & 13.83 & x \\
9 & 5.44 & 20.99 & 13.22 & 9.30 & 12.81 & 15.57 & 5.89 \\
10 & 5.26 & 23.82 & 15.23 & 11.24 & 11.83 & 16.73 & 9.70 \\
11 & 5.27 & 24.08 & 18.04 & 9.95 & 11.01 & 14.96 & 13.62 \\
12 & 5.09 & 22.31 & 16.48 & 9.81 & 10.94 & 14.69 & 14.82 \\
13 & 5.67 & 22.36 & 14.92 & 9.93 & 11.31 & 14.79 & 9.38 \\
14 & 5.45 & 20.73 & 13.85 & 10.51 & 10.59 & 15.60 & 16.05 \\
15 & 4.44 & 16.57 & 12.08 & 10.18 & 10.51 & 16.71 & 15.56 \\
16 & 3.93 & 14.04 & 11.09 & 9.79 & 9.65 & 15.79 & 10.34 \\
17 & 3.56 & 12.20 & 10.03 & 10.44 & 9.76 & 15.90 & 9.24 \\
18 & 3.57 & 11.68 & 9.46 & 10.90 & 10.41 & 16.03 & 8.55 \\
19 & 3.63 & 11.56 & 9.12 & 10.95 & 10.14 & 16.17 & 9.48 \\
20 & 3.60 & 11.38 & 9.33 & 10.87 & 9.91 & 16.35 & 9.43 \\
21 & 3.59 & 11.41 & 9.24 & 9.97 & 8.76 & 16.86 & 9.08 \\
22 & 3.61 & 11.56 & 9.50 & 10.44 & 9.73 & 16.59 & 9.50 \\
23 & 3.66 & 11.30 & 8.93 & 11.21 & 10.48 & 17.18 & 10.45 \\
24 & 3.65 & 12.18 & 9.37 & 11.06 & 10.51 & 17.65 & 10.51 \\
25 & 3.53 & 12.58 & 10.01 & 12.71 & 9.48 & 16.04 & 11.01 \\
26 & 3.71 & 11.80 & 9.61 & 10.43 & 10.40 & 17.85 & 12.80 \\
27 & 3.21 & 10.93 & 9.56 & 10.77 & 9.69 & 19.73 & 10.40 \\
28 & 3.79 & 11.57 & 9.32 & 11.90 & 9.32 & 22.84 & 11.86 \\
29 & 3.33 & 13.66 & 11.61 & 10.00 & 10.51 & 16.39 & 10.86 \\
30 & 3.92 & 13.34 & 10.66 & 8.86 & 8.66 & 14.20 & 13.53 \\
$31-35$ & 3.53 & 13.26 & 11.39 & 10.47 & 9.30 & 17.00 & 10.71 \\
$36-40$ & 3.60 & 13.21 & 10.85 & 13.02 & 11.35 & 16.08 & 13.12 \\
$41-50$ & 3.28 & 14.65 & 12.38 & 12.26 & 9.76 & 17.96 & 10.69 \\
$51<$ & 4.34 & 17.76 & 15.55 & 16.07 & 15.48 & 15.50 & .00 \\
\hline & & & & & & & \\
& & & & & & &
\end{tabular}

Body Height (Stature). Analyzing the data of Tables I, II, and III, as well Fig. 1, we may evaluate the differentiation of the variable body height during different ages. In the age group of 17 year olds, the curve of body height shows increases. After this age group and up to the age 40 year, body height has achieved its stable values (horizontal part of the curve) (WHO). The adults older than 40 years show decrease of the values of body height.

Difference between adults' on body height shows that adults between 18-30 years old have realized the higher values of body height $(1779.2 \mathrm{~cm})$, compared with other two groups of tested adults (Table IV). This fact can be explained with the phenomenon of acceleration (influence of psycho-socio-economical factors on growth and development of the humans), as well as with influence of age.

Table IV. Average values of Body Height for different age groups.

\begin{tabular}{lcc}
\hline \multicolumn{1}{c}{ Ages } & $\mathbf{N}^{\mathbf{0}}$ of entities & Body height \\
\hline $18-30$ & 7086 & 1779.2 \\
$31-40$ & 676 & 1775.0 \\
$41-50$ & 182 & 1762.0 \\
$>51$ & 70 & 1680.0 \\
\hline
\end{tabular}




\section{Stature}

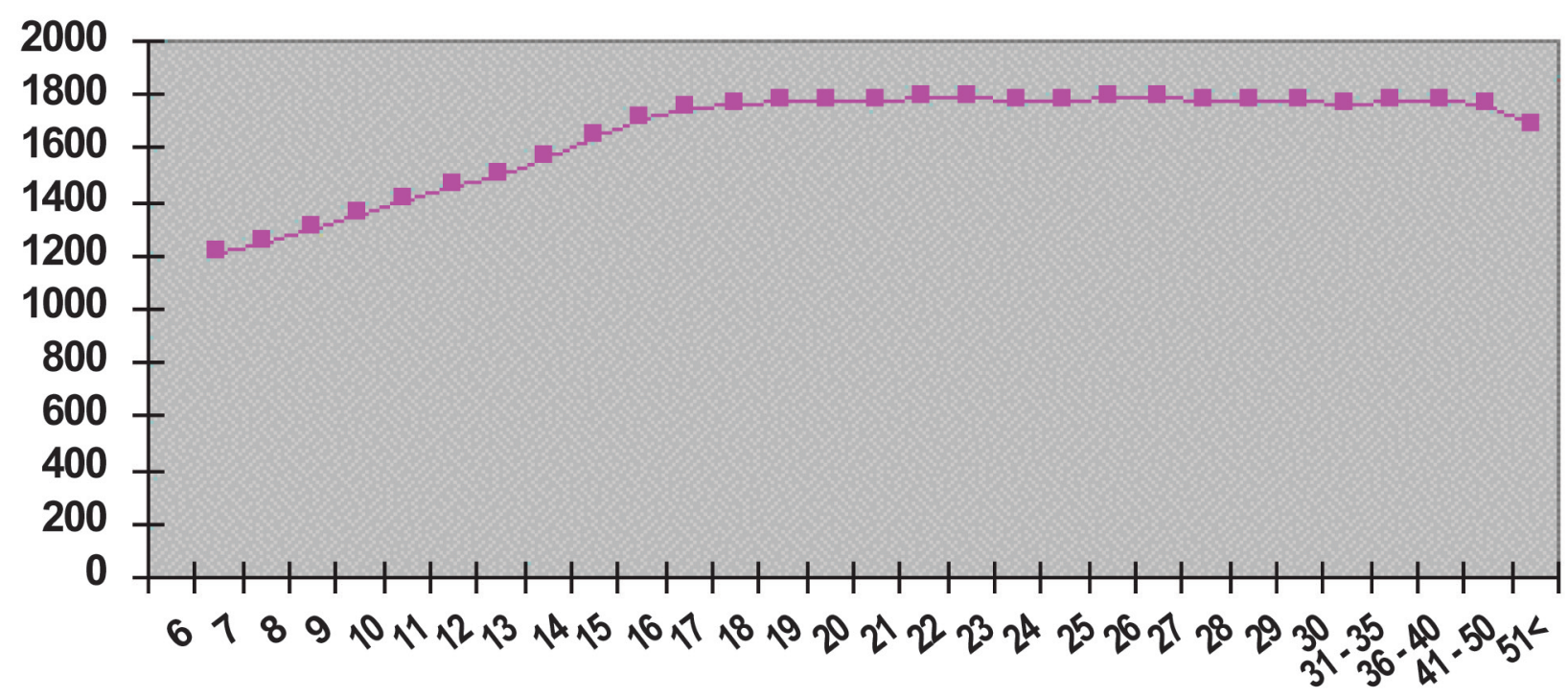

Fig. 1. Graphic presentation of the changes of body height, by age.

Body Weight. Body weight, from 6 years of age up to 50 years of age, consistently shows increase of its value. While, at the ages above 51 of age, body weight decreases rapidly.

Body Mass Index (BMI). For adults who have stopped growing, an increase in BMI is usually caused by an increase in body fat, while as children grow, their amount of body fat changes and so will their BMI (Percentage of body fat). For this reason BMI usually decreases during preschool years and then increases in adulthood (BMI). Even if, the healthy weight range for adults of a BMI of 20 to 25 is not a suitable measure for children, according to the results of BMI we can conclude that the individuals up to the age of 13 years old, shows to be underweight. To have more accurate results of BMI for children or adolescents, this variable must be corrected with regard to their age, as well gender (percentile charts).

The tested entities between ages 14 years and 35 years old, as well ages above 51 years old, according to their BMI, showed to be in normal weight. Whereas, the individuals' ages 36 years to 50 years, showed to be slightly overweight (Chau, 2008; Wollanski, 1985).

Systolic Blood Pressure and Diastolic Blood Pressure. Systolic and Diastolic Blood Pressure in all tested individuals, at different ages, have increased their values, but not above normal value (DeVries, 1986; McArdle, 1996; Scott, 2001).

Heart Rate and Absolute Maximal Oxygen Uptakes (VO $\mathbf{O}_{2}$ max.abs). Heart Rate and Absolute Maximal Oxygen Uptakes ( $\mathrm{VO}_{2}$ max.abs) show similar results. The better results of both variables have been reached in adults aged from 19 years old to 27 years. Both other extremities of tested individuals (younger and older than these ages) have been characterized with lower results of these two variables. While, the young individuals are still in the development period of their functional abilities, the older adults begin to lose these abilities (NISMAT; About.com, 2010; McArdle, 1996; DeVries, 1986; Scott, 2001).

Standard Deviation shows the similar dispersion of results at different ages, for values of all measured variables (Table II). Also, the normal dispersion of the results was verified by the Coefficient of Variation, which signifies the reliability of the measurements that were completed (Table III). The exceptions of this normal dispersion showed the individuals of age groups 13-14 years old, which have shown their higher values of Standard Deviation, and Coefficient of Variation on the variable of body height, which can be explained by the growth spurt during puberty that occurs at this age. 
REXHEPI, A. M.; BRESTOVCI, B. \& KRASNIQI, A. Características físicas en diferentes edades. Int. J. Morphol., 29(1):105-111, 2011.

RESUMEN: El objetivo de este trabajo fue estudiar, observar, y para aclarar la dinámica de crecimiento físico, así como los cambios de algunas variables morfométricas y fisiológicas de la población de Kosovo. En 17.894 hombres en Kosovo, de entre 6 y 51 años, se tomaron las siguientes medidas: Altura y peso corporal, IMC, presiones sistólica y diastólica, frecuencia cardíaca, VO máx. Los datos fueron procesados a través de los siguientes parámetros estadísticos descriptivos: media, desviación estándar y coeficiente de variación. La DS muestra la dispersión de los resultados de acuerdo a la edad. CV determina la fiabilidad de las mediciones que se hicieron. La curva de la altura del cuerpo entre 6-17 años de edad aumentó entre los 18 y 40 años de edad, mientras que para individuos de más de 40 años la curva disminuye. La altura corporal mostró que los adultos entre 18-30 años son más altos, en comparación con otros dos grupos. El peso corporal aumenta desde los 6 a los 50 años edad, mientras que después de los 51 años se produce rápidamente su disminución. De acuerdo a los valores de IMC, los individuos entre 6-13 años de edad presentaban bajo peso. Los individuos entre 1435 años y superiores a 51 años presentaban un peso normal. Los individuos entre 36-50 años, presentaron un ligero sobrepeso. Aumentaron las presiones sistólica y diastólica de acuerdo a la edad, pero no por encima del valor normal. Los mejores resultados de la frecuencia cardiaca y $\mathrm{VO}_{2}$ máx se alcanzaron en los adultos entre 19 y 27 años. $\mathrm{VO}_{2}$ máx.

PALABRAS CLAVE: Altura del cuerpo; Peso corporal; IMC; Presión sistólica; Presión diastólica; Frecuencia cardíaca;

\section{REFERENCES}

About.com. Sports Medicine. What is $\mathrm{VO}_{2} \max ?, 2010$. Available from: http://sportsmedicine.about.com/od/ anatomyandphysiology/a/ $/ \mathrm{VO}_{2}$ max.htm

Anthropometry, 2010. Available from: http://www.itech.net.au/ hfs/Hy-Fit_Manual.htm\#anthro

Body Mass Index (BMI). 2010. Available from: http:// www.betterhealth.vic.gov.au/bhcv2/bhcarticles.nsf/pages/ Body_Mass_Index_(BMI)

Centers for Disease Control and Prevention. Body Mass Index, 2010. Available from: http://www.cdc.gov/healthyweight/ assessing/bmi/

Chau, D.; Cho, L. M.; Jani, P. \& Jeor, S.T. Individualizing recommendations for weight management in the elderly. Curr. Opin. Clin. Nutr. Metab. Care, 11(1):27-31, 2008.

De Vries, H. A. Physiology of exercise: for Physical Education and Athletics. $4^{\text {th }}$ ed. Dubuque, Iowa, Vm. C. Brown Publishers, 1986.

Douglas, E. C. What does anthropometry tell us about the elder phenotype and design?. ICPA, 2008 Symposium: Anthropometry and design, 2008.

McArdle, W. D.; Katch, F. I. \& Katch, V. L. Exercise physiology. $4^{\text {th }}$ ed. Baltimore, Maryland, 1996.

NISMAT. Exercise Physiology Corner: Maximum Oxygen Consumption Primer, 2010. Available from: http:// www.nismat.org/physcor/max_o2.html
Rexhepi, A. Doracaku Antropologjik - Anthropological Digest. Kolegji UES «Eurosporti». Prishtina, University College for Sport Education «Eurosporti», 2008.

Rexhepi, A. Mjekësia Sportive - Sports Medicine. Ministria e Shëndetësisë, Kolegji UES «Eurosporti». Prishtina, Ministry of Health, University College for Sport Education «Eurosporti», 2009.

Rexhepi, A. \& Brestovci, B. Differences in bodily growth between young footballers and basketball players. Int. J. Morphol., 28(2):415-20, 2010.

Scott, K. P. \& Edward, T. H. Exercise Physiology: Theory And Application To Fitness and Performance. Boston, McGraw Hill, 2001.

World Health Organization, WHO. Physical Status. The use and interpretation of anthropometry, 1995.

Wolanski, N.; Teter, A. \& Kowalczyk, E. Adipose tissue distribution - changes with age and regional differences. Coll. Antropol., 223-7, 1985.

Correspondence to:

Agron Rexhepi

Str. "Sali Butka" Nr. 31/D

10020 Pristina

KOSOVA

Email: agronmrexhepi@gmail.com

Received: 08-09-2010

Accepted: 12-02-2011 